\title{
Hopes from the North-South summit
}

Third World

\section{struggles for}

\section{UN changes}

\section{Cancun, Mexico}

Last week's meeting of the heads of state of 22 developed and developing nations in Cancun could help to break the stalemate which has characterized recent efforts to devise new strategies for technical and financial assistance to Third World nations through agencies of the United Nations.

The meeting failed to provide the clear resolution which many had hoped for. In summing up the discussion, the cochairmen, Mexican President José Lopez Portillo and Canadian Prime Minister Pierre Trudeau, stated merely that there had been agreement to support preparations within the United Nations towards "global negotiations", the term being used to embrace efforts to overhaul the technical and financial agencies of the United Nations for the greater benefit of the Third World with no clear indication of when or how any charges would be implemented.

This failure to reach specific agreement reflected the opposition, particularly from the United States and the United Kingdom, to any attempt at moving decision-making responsibility for the financial agencies of the United Nations into the UN General Assembly, where they would all become subject to a one-country one-vote system of control. However, delegates attending the Cancun meeting expressed cautious optimism that it had at least provided a basis for more detailed discussions.

It had been hoped that two areas concerned with the applications of technology to development would receive a significant boost from the Cancun meeting. First, the World Bank's efforts to increase the amount of capital available for investment in energy projects in Third World countries. And second, the continued attempt to put into effect the recommendations of the UN Conference on Science and Technology for Development which took place in Vienna in 1979.

There was some slight but significant movement on both these fronts. The idea of an energy affiliate attached to the World Bank, thought to have been virtually scuppered by the opposition of the Reagan Administration, is far from dead. Many heads of state at Cancun spoke strongly in favour of the proposed affiliate. Particularly significant was the announcement by Saudi Arabia that it too supported the proposal. To the United States this seemed to imply the creation of a new "energy sector" to finance energy projects within the World Bank, although the United States and the United Kingdom insist that this should only be done if there were new funds for the purpose.

At the same time, members of several delegations informally expressed support for a new initiative, now backed by 20 developing countries which signed a declaration at a meeting in Caracas three weeks ago, to set up a special fund for helping developing countries to build up their scientific and technological infrastructure.

These funds would be used to carry out some of the recommendations of the Vienna meeting, with a suggested initial target for voluntary contributions of a million million dollars over the years 1982-87. One possible form for the fund would be to base it on the International Fund for Agricultural Development (IFAD), set up after the World Food Conference of 1972 with funding from the developed nations, the oil-producing nations and the developing nations.

But the differences that remain, both on the appropriate way of raising capital for energy projects in the Third World and on

\section{Monkey business hits university laboratory}

One of Britain's largest and best laboratory breeding colonies of rhesus monkeys is finally to be disbanded despite the fact that it has not been possible to import the animals from their usual source for the past three years. About half the monkeys are likely to find homes elsewhere but the other half may be killed - ten of them already have been - because they harbour a virus which can be fatal to man.

The virus is herpes simian B virus, with which monkeys can be either acutely or latently infected. An animal in the former state is very dangerous since the virus can be passed on to man through a bite; most of the recorded human infections of this type have been fatal. By contrast, animals which carry the virus in latent form pose no threat to humans except for the possibility of reactivation of the virus to its infectious form in conditions of severe stress. That possibility seems remote to judge by the lack of concern that many of the monkeys in zoos and wild life parks carry the virus in latent form.

The University of Birmingham, however, became particularly concerned about its monkeys in the wake of the death in 1978 of one of its staff from smallpox contracted, it is believed, from a virus that had escaped from one of their laboratories. That incident, the fact that the Medical Research Council had just issued new guidelines on the hazards of simian virus and the general state and age of the housing for their rhesus monkey colony, led the University of Birmingham to ask the Health and Safety Executive to give advice on the safety standards of the monkey the best method of building up their scientific and technological infrastructure, reflect the wide gulf between the free market ideology of the United States and the interventionist stance of most Third World gavernments.

On food, for example, President Reagan had announced previously in a speech in Philadelphia that the United States intended to shift its aid efforts towards market-oriented qualities that would create "self-sustaining capacity" for research and innovation, and stimulation of jobcreating entrepreneurship in rural areas.

Those attending the Cancun meeting agreed that priority should be given to finding ways in which developing countries could raise their own food production rather than to providing direct food aid.

But several developing countries also pushed for more direct intervention, for example, in the setting up of large emergency food stockpiles to compensate for poor harvests, and for greater efforts to establish a world food system embracing both production and distribution.

Discussions on both energy and food

housing. The upshot was that the university decided that it would cost $£ 250,000$ to modernize the building - a figure believed in some quarters to have been wildly inflated. In any case the university decided it could not afford modernization and that the colony would have to go.

That decision was made in September 1980 (although work on the monkeys carrying latent virus had been suspended in February of the previous year for lack of adequate safety). Following the decision Dr J. Marston, a qualified veterinary surgeon who had been closely involved with the maintenance of the colony for several years, suggested that he should be allowed to remove the monkeys to private housing and breeding facilities which he hoped to establish. The university agreed in principle but, after considerable capital had been raised, Dr Marston's plans were thwarted by the Home Office which was not satisfied with the proposed facilities. According to Dr Marston, the Home Office moved very slowly to its final decision and three weeks before it was finalized, at the end of September, the university threatened to start killing off the monkeys. Two weeks after the decision, on 12 October, the university ordered the killing of the infected animals at the rate of ten per day. Ten were killed with the participation, at his own insistence, of Dr Marston but a stay of execution was then issued. Dr Marston is now trying to find homes for all the monkeys including those with the latent virus, Home Office rules permitting.
Peter Newmark 
were generally thought to have moved forward at Cancun, perhaps providing a basis for later, more substantial, agreements. But the movement which several national heads such as Mrs Thatcher and French President Francois Mitterrand claimed was made in the direction of the "global negotiations" being demanded by the more militant of the developing nations was so small as to be virtually imperceptible.

David Dickson

\section{German cancer centre}

\section{Commission meets}

The first meeting has taken place of the International Commission appointed to look into the continuing problems of the German Cancer Research Centre in Heidelberg (see Nature 1 October, p.328). The commission spent 21-23 October in Heidelberg talking to all parties concerned and expects to complete its report in midDecember for delivery by the end of the year.

The task of the commission, under the chairmanship of Sir Michael Stoker, is to carry out an impartial investigation of the problems of governance of the centre and the quality of its research programme following the resignation in June of the director, Dr Hans Neurath. On 23 September Dr Neurath made clear his case saying that his plan to improve the quality of research at the centre had been obstructed and that the institution was "plagued by serious and perhaps irreconcilable conflicts of interest", largely stemming from an "old established majority".

While in Heidelberg the commission met, among others, Dr Neurath, the heads and/or staff representatives of all eight of the institutes that make up the centre and Dr Wolfgang Finke, chairman of the centre's supervisory body, the Kuratorium. The commission also reviewed recent publications by the staff of the centre.

The commission is likely to focus its attention on the Scientific Council of the centre, an internal body consisting of the eight heads of institute together with one other member of each institute who is elected by the staff. As it stands, any director of the centre wishing to make major changes in its activities would need either to have the majority support of the Scientific Council or be prepared to try and push ahead regardless. It is clear that Dr Neurath's proposals to bolster the quality and quantity of basic research at the expense of some clinical therapy and anticancer drug screening did not enjoy the support of the Scientific Council.

It will be for the next director, not the commission, to decide what policy to implement. He or she is not likely to be chosen until after the commission has reported but an announcement of the interim director is due in mid-November. The commission must hope that its advice leads to the possibility of effective direction next time round.

\section{New improved PWRs}

The task force appointed during the summer to streamline the design of a pressurized water reactor (PWR) suitable for British conditions has worked swiftly. Its new reference design was adopted by the Central Electricity Generating Board last week. The National Nuclear Corporation, for whom the task force did its work, will now draw up detailed specifications based on the reference design for Britain's first PWR planned to be built at Sizewell in Suffolk. The detailed design should be published next April or May, but the corporation plans to have an estimate of cost within two months.

The task force's apparent success follows on the nuclear corporation's earlier failure to design a satisfactory British PWR. The corporation's efforts were scrapped by the Department of Energy after the estimated cost of the reactor began to soar, largely due to the incorporation of extra safety features. The department appointed Dr Walter Marshall, chairman of the UK Atomic Energy Authority, to lead the task force to come up with a cheaper design quickly.

The details of the new reference design have not been released, but it is thought to resemble closely the standardized nuclear power plant system, SNUPPS, on which PWRs built by Westinghouse in the United States are based. It is unlikely that it retains any of the extra safety features incorporated in the previous attempted design, which included extra emergency core cooling systems, modified coolant pumps and extra thick concrete shielding.

The task force's design has taken only three months. Speed was important to meet the deadline set for the public inquiry into the siting of the reactor at Sizewell due by the end of 1982. A detailed specification of the reactor must be published well before the inquiry to permit public scrutiny.

Judy Redfearn

\section{Oil pollution}

\section{British problems}

The British government machinery for coping with major oil spills is inadequate, according to the Royal Commission on Environmental Pollution, whose latest report on oil pollution of the sea was published last week. The problem is that too many government departments, local and other interested bodies, often with conflicting interests, are involved in cleanup operations. The commission's report recommends that responsibility for dealing with the larger spills should be vested solely with the Marine Pollution Control Unit, which should be strengthened to cope with the task and made responsible to both the
Departments of Trade and the Environment.

The commission's report is the outcome of three years of study begun when the Amoco Cadiz spilt 200,000 tons of crude oil after running aground in the English Channel off the north coast of France. Although British coasts escaped extensive pollution (the coasts of Brittany bore the brunt), the incident reinforced public anxiety over the environmental consequences of major oil spills. The then Labour government requested the royal commission to investigate the general issue and accordingly its report is wide ranging, including sources of oil pollution, the consequences of both chronic pollution and major spills for marine life and public amenities and international and national attempts at prevention and control.

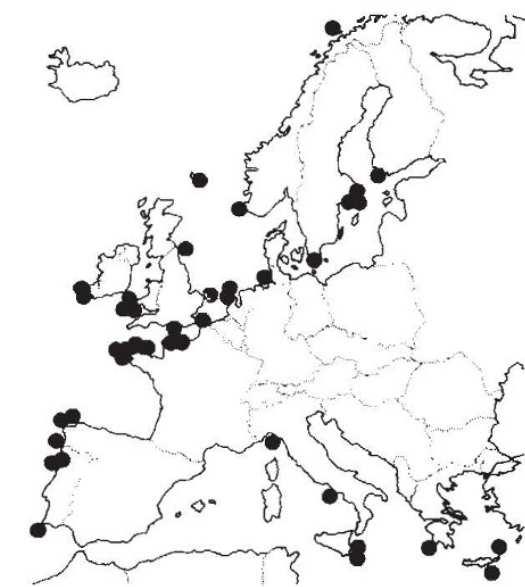

Sites of major oil spills around Europe

The report, however, has one word of reassurance. The commission found that neither chronic oil pollution nor major spills pose a permanent threat to the marine environment. Oil slicks affect marine life only for as far as they extend and as long as they last. Once they disperse, marine systems usually recover over a period of a few months to several years. Although sea birds are more susceptible to the effects of both chronic pollution and major spills than are fish, the commission found no evidence that any breeding colonies in Britain are currently threatened. Intertidal ecosystems are likely to suffer more than marine life in the open sea.

The commission found that research on the effects of oil on marine animals is adequate but that a lack of knowledge of the natural variability of marine systems makes it difficult to assess the singular effects of oil spills. Hence, rather than more research it urges greater coordination, in particular between research on oil and that on other pollutants such as heavy metals and polychlorinated biphenyls.

Despite the reassurance, however, the commission says that the immediate effects of major oil spills are sufficiently unpleasant to warrant greater effort at prevention and a more efficient way of coping with accidents. British government policy comes in for a drubbing. According to the 